\title{
PENGARUH EMOTIONAL INTELLIGENCE TERHADAP ACADEMIC ACHIEVEMENT: LOCUS OF CONTROL SEBAGAI MEDIATOR (Studi Pada Siswa SMA N 9 Padang)
}

\author{
Rice Afriani, Febsri Susanti \\ Sekolah Tinggi Ilmu Ekonomi KBP Padang \\ febsrisusanti@akbpstie.ac.id
}

\begin{abstract}
ABSTRAK
Pendidikan pada dasarnya adalah usaha sadar untuk menumbuh kembangkan potensi sumber daya manusia dengan cara mendorong dan memfasilitasi kegiatan belajar. Belajar adalah aktivitas terstruktur yang dilakukan seseorang untuk memperoleh pengetahuan. Pemerintah melalui PERMENDIKNAS nomor 71 tahun 2013 mengenai Struktur Kurikulum menjelaskan bahwa Kurikulum 2013 bertujuan untuk mempersiapkan manusia Indonesia agar memiliki kemampuan hidup sebagai pribadi dan warga negara yang beriman, produktif, kreatif,inovatif, dan afektif serta mampu berkontribusi pada kehidupan bermasyarakat, berbangsa, bernegara, dan peradaban dunia. Pada pendidikan sekolah menengah atas, faktor academic achievement sangat diperhitungkan pada penilaian akhir dari seorang siswa. Di kota Padang sekolah-sekolah yang mempunyai popularitas yang cukup tinggi (dalam hal prestasi akademik atau pun non akademik) sangat konsisten pada penilaian prestasi academic achievement. Atas dasar permasalahan yang di temukan di SMA N 9 Padang. Diketahui bahwa pengaruh Emosional terhadap Locus Of Control sangat berpengaruh signifikan. Oleh karena itu peneliti mencoba untuk menganalisis bagaimana satu variabel atau lebih berpengaruh terhadap variabel lain. Penelitian ini menggunakan pendekatan kuantitatif dengan metode random sampling. Sampel pada penelitian ini adalah siswa kelas $\mathrm{X}$, XI, dan XII yang berjumlah 100 orang.
\end{abstract}

Kata Kunci : Emotional Intelligence, Academic Achievement, Locus Of Control. 


\section{PENDAHULUAN}

\section{Latar Belakang}

Pendidikan merupakan suatu kebutuhan pokok yang diperlukan bagi setiap manusia dalam memperoleh ilmu dan wawasan. Pendidikan dibedakan atas dua macam, yaitu: pendidikan formal dan pendidikan non formal. Tujuan dari pendidikan formal maupun non formal adalah sarana dalam membentuk karakter kepribadian anak. Oleh karena itu pendidikan dalam sekolah maupun lingkungan keluarga merupakan salah satu asset penting bagi setiap anak, yang nantinya diharapkan mampu membentuk pola perilaku dan wawasan anak.

Dalam dunia pendidikan formal, pentingnya pengukuran prestasi akademik tidaklah dapat disangsikan lagi. Sebagaimana diketahui, proses pendidikan formal adalah suatu proses yang kompleks yang memerlukan waktu, dana dan usaha serta kerjasama berbagai pihak. Berbagai aspek dan faktor terlibat dalam proses pendidikan secara keseluruhan. Tidak ada pendidikan yang secara sendirinya berhasil mencapai tujuan yang digariskan tanpa interaksi berbagai faktor pendukung yang ada dalam sistem pendidikan tersebut. Betapa jelasnya pun suatu tujuan pendidikan telah digariskan, tanpa usaha pengukuran maka akan mustahil hasilnya dapat diketahui. Tidaklah layak untuk menyatakan adanya suatu kemajuan atau keberhasilan program pendidikan tanpa memberikan bukti peningkatan atau pencapaian yang diperoleh. Bukti peningkatan atau pencapaian inilah yang harus diambil dari pengukuran prestasi secara terencana.

Pencapaian pada academic achievement juga dipengaruhi oleh beberapa hal yang harus ditinjau secara jelas. Menurut Azwar (2004) secara umum, ada dua faktor yang mempengaruhi prestasi akademik seseorang, yaitu faktor internal dan factor eksternal. Faktor internal meliputi antara lain faktor fisik dan faktor psikologis. Faktor fisik berhubungan dengan kondisi fisik umum seperti penglihatan dan pendengaran. Faktor psikologis menyangkut faktor-faktor non fisik, seperti minat, motivasi, bakat, intelegensi, sikap dan kesehatan mental. Faktor eksternal meliputi faktor fisik dan faktor sosial. Faktor fisik menyangkut kondisi tempat belajar, sarana dan perlengkapan belajar, materi pelajaran dan kondisi lingkungan belajar. Faktor sosial menyangkut dukungan sosial dan pengaruh budaya.

Locus of control merupakan salah satu variabel kepribadian (personality), yang didefenisikan sebagai keyakinan individu terhadap mampu tidaknya mengontrol nasib (destiny) sendiri (Kreitner dan Kinicki, 2005). Sedangkan Locus kendali sebagai tingkat dimana individu yakin bahwa mereka adalah penentu nasib mereka (Robbins dan Judge, 2007). Dapat disimpulkan bahwa individu yang memiliki keyakinan bahwa nasib atau event dalam kehidupannya berada dibawah kontrol dirinya, dikatakan individu tersebut memiliki internal locus of control. Sementara individu yang memiliki keyakinan bahwa lingkungan lah yang mempunyai kontrol terhadap nasib atau event yang terjadi dalam kehidupannya dikatakan individu tersebut memiliki eksternal locus of control. Kreitner and Kinichi (2005) mengatakan bahwa hasil yang dicapai locus of control internal dianggap berasal dari aktifitas dirinya, sedangkan pada individu locus of control eksternal menganggap bahwa keberhasilan yang dicapai dikontrol dari keadaan sekitarnya.

Pada pendidikan sekolah menengah atas faktor academic achievement sangat diperhitungkan pada penilaian akhir dari seorang siswa. Di kota Padang 
sekolah-sekolah yang mempunyai popularitas yang cukup tinggi (dalam hal prestasi akademik atau pun non akademik) sangat konsisten dalam penilaiannya dalam academic achievement. Adapun tujuan penelitian dalam hal ini adalah : 1 . Mengetahui pengaruh emotional intelligence terhadap locus of control siswa / siswi SMA Negeri 9 Padang. 2. Mengetahui pengaruh locus of control terhadap academic achievement siswa / siswi SMA Negeri 9 Padang. 3. Mengetahui pengaruh emotional intelligence terhadap academic achievement siswa / siswi SMA Negeri 9 Padang Dengan locus of control Sebagai variabel mediasi.

\section{METODE PENELITIAN}

Penelitian ini menggunakan pendekatan kuantitatif yang digunakan untuk menganalisis bagaimana satu variabel atau lebih berpengaruh terhadap variabel lain dan hubungan sebab-akibat antara variabel dijelaskan dengan hipotesis. Semua data dan informasi yang dikumpulkan dari responden menggunakan kuesioner dan kemudian hasilnya akan dijelaskan untuk menjawab pertanyaan penelitian. Penelitian ini bertujuan untuk menguji hipotesis. Hipotesis pengujian-studi adalah studi yang menjelaskan sifat hubungan tertentu, atau membuat perbedaan yang ada diantara kelompok atau masing-masing dari dua atau lebih faktor (Sekaran, 2009).

\section{HASIL PENELITIAN}

Penelitian dilakukan dari tanggal 14 September 2016 sampai dengan 09 Oktober 2016 di SMA N 9 Padang. Untuk mengetahui karakteristik responden secara menyeluruh, maka dilakukan penyebaran kuesioner penelitian kepada 100 siswa siswi kelas X, XI dan XII. Berdasarkan hasil penelitian yang dilakukan, maka dapat dikelompokkan karakteristik responden sebagai berikut :

\section{Tabel 1}

Karakteristik Responden Berdasarkan Jenis Kelamin

\begin{tabular}{|c|c|c|c|}
\hline No & Jenis Kelamin & Frekuensi & Persentase \% \\
\hline 1 & Perempuan & 33 & 34,7 \\
\hline 2 & Laki-laki & 62 & 65,3 \\
\hline & Total & 95 & 100,0 \\
\hline
\end{tabular}

Sumber: Diolah dari kuesioner dengan SPSS 17

Dari Tabel 1 diketahui bahwa responden yang berpatisipasi pada penelitian ini berdasarkan jenis kelamin adalah 62 orang perempuan dengan persentase $65.3 \%$, dan laki-laki 33 orang dengan persentase $34.7 \%$. Dapat dilihat bahwa siswa perempuan lebih banyak dari pada siswa laki-laki.

\section{Tabel 2}

Karakteristik Responden Berdasarkan Umur

\begin{tabular}{|c|c|c|c|}
\hline No & Umur & Jumlah & Persentase \% \\
\hline 1 & 14 & 4 & 4,2 \\
\hline 2 & 15 & 26 & 27,4 \\
\hline 3 & 16 & 34 & 35,8 \\
\hline 4 & 17 & 29 & 30,5 \\
\hline 5 & 18 & 2 & 2,1 \\
\hline & Total & 95 & 100,0 \\
\hline
\end{tabular}

Sumber: Diolah dari kuesioner dengan SPSS 17 
Dari tabel 2 dapat terlihat bahwa responden yang paling banyak berpartisipasi pada penelitian ini berusia 16 tahun dengan persentase $35.8 \%$. Dan responden yang paling sedikit berpartisipasi berusia 18 tahun dengan persentase $2.1 \%$.

Tabel 3

Karakteristik Responden Berdasarkan Nilai Semester Terakhir

\begin{tabular}{|c|c|c|c|}
\hline No & Nilai Semester & Frekuensi & Persentase \% \\
\hline 1 & $80-84$ & 32 & 34,7 \\
\hline 2 & $85-90$ & 53 & 55,8 \\
\hline 3 & $91-96$ & 12 & 9,5 \\
\hline & Total & 95 & 100,0 \\
\hline
\end{tabular}

Sumber: Diolah dari kuesioner dengan SPSS 17

Dari tabel 3 dapat terlihat bahwa responden dengan nilai 85 - 90 adalah yang paling banyak dengan persentase $55.8 \%$. Sedangkan yang paling sedikit adalah nilai 91 -96 dengan persentase $9.5 \%$.

Tabel 4

Karakteristik Responden Berdasarkan Kelas

\begin{tabular}{|c|c|c|c|}
\hline No & Kelas & Frekuensi & Persentase \% \\
\hline 1 & $\mathrm{X}$ & 34 & 35,8 \\
\hline 2 & $\mathrm{XI}$ & 31 & 32,6 \\
\hline 3 & XII & 30 & 31,6 \\
\hline & Total & 95 & 100,0 \\
\hline
\end{tabular}

Sumber: Diolah dari kuesioner dengan SPSS 17

Dari tabel 4 dapat terlihat bahwa responden yang paling banyak berpartisipasi pada kelas $\mathrm{X}$ dengan persentase $35.8 \%$. Sedangkan yang paling sedikit adalah kelas XII dengan persentase $31.6 \%$.

Tabel 5

Karakteristik Responden Berdasarkan Jurusan

\begin{tabular}{|c|c|c|c|}
\hline No & Jurusan & Frekuensi & Persentase \% \\
\hline 1 & IPA & 89 & 93,7 \\
\hline 2 & IPS & 6 & 6,3 \\
\hline & Total & 95 & 100,0 \\
\hline
\end{tabular}

Sumber: Diolah dari kuesioner dengan SPSS 17

Dari tabel 5 diatas diketahui responden dari kelas IPA berpartisipasi paling banyak dalam penelitian ini dengan persentase $93.7 \%$. Sedangkan yang paling sedikit adalah responden dari jurusan IPS dengan persentase $6.3 \%$.

Tabel 6

Karakteristik Responden Berdasarkan Pekerjaan Orang Tua

\begin{tabular}{|c|c|c|c|}
\hline No & Pekerjaan Orang Tua & Frekuensi & Persentase \% \\
\hline 1 & PNS/BUMN/ABRI & 33 & 34,7 \\
\hline 2 & Wiraswasta & 32 & 33,7 \\
\hline 3 & Buruh & 9 & 9,5 \\
\hline 4 & Lain-lain & 21 & 22,1 \\
\hline & Total & 95 & 100,0 \\
\hline
\end{tabular}

Sumber: Diolah dari kuesioner dengan SPSS 17 
Dari tabel 6 dapat terlihat bahwa responden yang paling banyak berpartisipasi pada penelitian ini orangtuanya bekerja sebagai PNS/BUMN/ABRI dengan persentase $34.7 \%$. Sedangkan yang paling sedikit orangtuanya yang bekerja sebagai BURUH dengan persentase $9.5 \%$.

Tabel 7

Karakteristik Responden Berdasarkan Organisasi

\begin{tabular}{|c|c|c|c|}
\hline No & Banyak Organisasi & Frekuensi & Persentase \% \\
\hline 1 & 0 Organisasi & 72 & 75,8 \\
\hline 2 & 1 Organisasi & 20 & 21,0 \\
\hline 3 & 2 Organisasi & 3 & 3,2 \\
\hline & Total & 95 & 100,0 \\
\hline
\end{tabular}

Sumber: Diolah dari kuesioner dengan SPSS 17

Dari tabel 7 dapat dilihat bahwa siswa lebih banyak tidak mengikuti organisasi dengan persentase $75.8 \%$ dan hanya sedikit siswa yang mengikuti 2 organisasi dengan persentase $3.2 \%$.

\section{Tabel 8}

Karakteristik Responden Berdasarkan Jumlah Ekstrakurikuler

\begin{tabular}{|c|c|c|c|}
\hline No & $\begin{array}{c}\text { Jumlah } \\
\text { Ekstrakulikuler }\end{array}$ & Frekuensi & Persentase \% \\
\hline 1 & 0 & 55 & 57,9 \\
\hline 2 & 1 & 33 & 34,7 \\
\hline 3 & $2-3$ & 7 & 7,4 \\
\hline & Total & 95 & 100,0 \\
\hline
\end{tabular}

Sumber: Diolah dari kuesioner dengan SPSS 17

Dari tabel 8 dapat dilihat bahwa responden yang tidak mengikuti ekstrakurikuler merupakan yang paling banyak dengan persentase $57.9 \%$ dan yang paling sedikit responden yang mengikuti lebih dari dua ekstrakurikuler dengan persentase $7.4 \%$

\section{Hasil Uji Statistik}

Uji Sampel t-Test dengan mengunakan program Smart PLS dengan tidak mengasumsikan normalitas dan distribusi data, PLS menggunakan nonparametric test untuk menentukan tingkat signifikan dari discriminant validity, dimana nilai $\mathrm{t}$ (t-value) yang dihasilkan dengan menjalankan alogaritma bootsraping pada SmartPLS. Yang digunakan untuk menentukan diterima atau tidaknya hipotesis yang diajukan.

Hipotesis akan didukung apabila nilai t-value melebihi 1.96. Penelitian ini menguji hubungan antara pengaruh emotional intelligence terhadap academic achievement dengan locus of control sebagai variabel mediasi. Respondennya adalah siswa/siswa SMA Negeri 9 Padang. Berdasarkan tabel 9 tidak semua hipotesis dapat diterima karena ada beberapa hubungan yang mempunyai tstatistik dibawah 1.96 . 
Tabel 9

Path Coefficients (Mean, STDEV, T-Values)

\begin{tabular}{|l|c|c|c|c|c|}
\hline & $\begin{array}{c}\text { Original } \\
\text { Sample (O) }\end{array}$ & $\begin{array}{c}\text { Sample } \\
\text { Mean (M) }\end{array}$ & $\begin{array}{c}\text { Standard } \\
\text { Deviation } \\
(\text { STDEV })\end{array}$ & $\begin{array}{c}\text { T Statistics } \\
(\mid \text { O/STERR })\end{array}$ & T-Values \\
\hline $\begin{array}{l}\text { AEE -> Emotional } \\
\text { Intelligence }\end{array}$ & 0.245799 & 0.244461 & 0.039432 & $\mathbf{6 . 2 3 3 5 5 0}$ & 0.039432 \\
\hline C -> Locus Of Control & 0.551597 & 0.535852 & 0.082327 & $\mathbf{6 . 7 0 0 1 0 9}$ & 0.082327 \\
\hline $\begin{array}{l}\text { Emotional Intelligence } \\
\text {-> Academic } \\
\text { Achievement }\end{array}$ & -0.142982 & -0.160307 & 0.108370 & $\mathbf{1 . 3 1 9 3 8 9}$ & 0.108370 \\
\hline $\begin{array}{l}\text { Emotional Intelligence } \\
\text {-> Locus Of Control }\end{array}$ & -0.029421 & -0.025971 & 0.013413 & $\mathbf{2 . 1 9 3 4 8 6}$ & 0.013413 \\
\hline $\begin{array}{l}\text { INT -> Locus Of } \\
\text { Control }\end{array}$ & 0.211744 & 0.215306 & 0.113950 & $\mathbf{1 . 8 5 8 2 1 4}$ & 0.113950 \\
\hline $\begin{array}{l}\text { Locus Of Control -> } \\
\text { Academic } \\
\text { Achievement }\end{array}$ & 0.097079 & 0.089284 & 0.138420 & $\mathbf{0 . 7 0 1 3 4 0}$ & 0.138420 \\
\hline $\begin{array}{l}\text { PO -> Locus Of } \\
\text { Control }\end{array}$ & 0.536384 & 0.514100 & 0.078731 & $\mathbf{6 . 8 1 2 8 5 2}$ & 0.078731 \\
\hline $\begin{array}{l}\text { RE -> Emotional } \\
\text { Intelligence }\end{array}$ & 0.499657 & 0.492924 & 0.043119 & $\mathbf{1 1 . 5 8 7 8 9 1}$ & 0.043119 \\
\hline $\begin{array}{l}\text { UE -> Emotional } \\
\text { Intelligence }\end{array}$ & 0.393417 & 0.389567 & 0.053432 & $\mathbf{7 . 3 6 3 0 0 8}$ & 0.053432 \\
\hline Sumber: Output SmartPLS & $2.0(2017)$ & & & \\
\hline
\end{tabular}

Sumber: Output SmartPLS 2.0 (2017)

Pada tabel menunjukkan pengaruh yang signifikan terhadap hubungan emotional intelligence dengan locus of control. Pada T statistik dengan nilai yang lebih besar daripada $\mathrm{T}$ table (1.96). Hubungan antara variabel tes menunjukkan bahwa pengaruh emotional intelligence terhadap locus of control adalah signifikan pada $\mathrm{a}=0.05$ dengan nilai statistic $2.193>1.96$.

Hasil selanjutnya adalah tidak signifikan pengaruh locus of control dan academic achievement. Hal ini terlihat pada $\mathrm{T}$ statistik dengan nilai yang lebih kecil dari pada $\mathrm{T}$ table (1.96). Hubungan antara variabel tes menunjukkan bahwa pengaruh locus of control terhadap academic achievement adalah tidak signifikan pada $\mathrm{a}=0.05$ dengan nilai statistik $0.701<1.96$.

Kemudian hasil selanjutnya juga menunjukkan pengaruh yang tidak signifikan dengan nilai T-statistik yang lebih kecil dari 1.96. Hubungan antara variabel tes menunjukkan bahwa pengaruh emotional intelligence terhadap academic achievement adalah tidak signifikan pada $\mathrm{a}=0.05$ dengan nilai statistik $1.319>1.96$. 
Kesimpulan Hipotesis

\begin{tabular}{|c|c|}
\hline $\begin{aligned} \text { T statistic }: & 2.193>1,96 \\
\text { Hipotesis 1: } & \text { Emotional Intelligence } \\
& \text { berpengaruh terhadap Locus } \\
& \text { of Control }\end{aligned}$ & $\begin{array}{l}\text { Hipotesis: Diterima } \\
\text { Ini berarti Emotional } \\
\text { intelligence Berpengaruh } \\
\text { positif terhadap locus of } \\
\text { control }\end{array}$ \\
\hline $\begin{aligned} \text { T statistic }: & 1.319<1,96 \\
\text { Hipotesis 2: } & \text { Emotional Intelligence } \\
& \text { Berpengaruh terhadap } \\
& \text { Academic Achievement }\end{aligned}$ & $\begin{array}{l}\text { Hipotesis: Ditolak } \\
\text { Karena Emotional intelligence } \\
\text { terhadap academic } \\
\text { achievement } \\
\text { Tidak berpengaruh positif }\end{array}$ \\
\hline $\begin{array}{ll}\text { T statistic } & : 0.701<1,96 \\
\text { Hipotesis } & \text { 3 Locus Of Control tidak } \\
& \text { berpengaruh } \\
& \text { Academic Achievement dan } \\
& \text { Peran mediasi Locus of } \\
& \text { Control juga Tidak } \\
& \text { berpengaruh } \\
& \text { Emosional Intelligence dan } \\
& \text { Academic Achievement }\end{array}$ & $\begin{array}{l}\text { Hipotesis: Ditolak } \\
\text { Ini berarti Locus Of Control } \\
\text { tidak berpengaruh positif } \\
\text { terhadap academic } \\
\text { achievement }\end{array}$ \\
\hline
\end{tabular}

\section{Pembahasan Hasil Penelitian}

\section{Emotional Intelligence dengan Locus of Control}

Dari hasil Tabel diatas, dapat terlihat bahwa pada hipotesis 1 dinyatakan ada pengaruh . Dapat dilihat dari hasil t-statistiknya yang lebih besar dari $1.96(2.193$ < 1.96). Hal ini berarti hipotesis 1 diterima dengan artian bahwa variabel emotional intelligence yang terdiri dari beberapa dimensi yaitu The appraisal and expression of emotion, The regulation of emotion, The utilization of emotion, memiliki pengaruh terhadap variabel locus of control siswa/siswi SMA N 9 Padang.

Hal ini memperlihatkan bahwa locus of control akan memberikan pengaruh terhadap pertambahan umur seseorang. Dalam siswa/siswa SMA N 9 Padang yang memiliki umur diantara 14 sampai 18 tahun belum memberikan andil terhadap pengendalian locus of control pada diri mereka.

\section{Emotional Intelligence dengan Academic Achievement}

Penelitian ini menguji pengaruh emotional intelligence terhadap academic achievement. Penelitian ini lakukan untuk siswa/siswi SMA N 9 padang. Dari table, kita dapat melihat hipotesis yang signifikan.

Hipotesis 2 adalah tidak signifikan, emotional intelligence tidak berpengaruh signifikan terhadap academic achievement siswa/siswi, karena nilai T-statistik (1.319) kecil dari 1.96 ( $\mathrm{T}$ statistik $<\mathrm{T}$ tabel). Ini berarti bahwa emotional intelligence tidak memiliki pengaruh yang signifikan terhadap academic achievement siswa/siswi SMA N 9 Padang.

Dari hasil keseluruhan terhadap hubungan emotional intelligence dengan academic achievement memperlihatkan hubungan yang tidak signifikan. Hasil ini didukung oleh penelitian sebelumnya oleh Rahnama and Abulmaleki (2009.

Locus of Control dengan Academic Achievement dan Peranan Locus of Control sebagai variable Mediator 
Penelitian ini menguji pengaruh locus of control terhadap academic achievement pada siswa/siswi SMAN 9 Padang. Dari tabel, kita dapat melihat bahwa hipotesis tidak berpengaruh secara signifikan.

Hipotesis 3 tidak signifikan, locus of control belum signifikan terhadap academic achievement, karena nilai T statistik (0.701) lebih rendah dari 1.96 (T statistik < $\mathrm{T}$ tabel). Ini berarti bahwa locus of control siswa/siswi SMAN 9 Padang, tidak berpengaruh secara signifikan terhadap academic achievement.

Hasil ini tidak mendukung beberapa penelitian sebelumnya,yang mengatakan locus of control memiliki pengaruh yang signifikan terhadap academic achievement. Anderson, Hattie, dan Hamilton (2005).

Dari penjelasan di atas, kita dapat melihat bahwa locus of control tidak berpengaruh negatif terhadap academic achievement. Ini juga berarti bahwa locus of control tidak bisa menjadi mediator antara emotional intelligence dan academic achievement. Karena variabel mediasi hanya bekerja jika pengaruh antara variabel dependen dan variabel independen dengan mediator positif.

\section{Kesimpulan}

Penelitian ini menggunakan tiga variabel, ada emotional intelligence, locus of control, dan academic achievement. Penelitian ini dilakukan dengan menyebarkan kuesioner kepada 100 orang siswa/siswi di SMA N 9 Padang, namun hanya 95 kuesioner dapat diproses. Data dalam penelitian ini diolah dengan menggunakan Microsoft Excel, SPSS 17, dan SmartPLS 2.0. Seperti yang telah dijelaskan dalam bab-bab sebelumnya, ada tiga hipotesis yang diajukan dalam penelitian ini dan hasil analisis menunjukkan bahwa ada dua hipotesis yang signifikan positif dan satu negatif dan tidak signifikan. Semua hipotesis adalah jawaban dari pertanyaan penelitian yang diajukan dalam penelitian ini

Berdasarkan hasil pengujian SEM (structural equational modeling) dengan SmartPLS software menyimpulkan sebagai berikut:

1. Tujuan dari penelitian ini adalah untuk mengetahui tentang pengaruh emotional intelligence terhadap academic achievement siswa/siswi dan menggunakan locus of control sebagai mediator di SMA N 9 Padang. Penelitian ini dilakukan dengan menggunakan distribusi kuesioner kepada siswa/siswi kelas X, XI dan XII SMA $\mathrm{N} 9$ Padang. Pengukuran variabel adalah 30 item untuk emotional intelligence, dan 24 item untuk locus of control, dan 1 item untuk academic achievement. Data diolah dengan menggunakan SmartPLS 2.0 untuk windows.

2. Berdasarkan uji hipotesis, emotional intelligence berpengaruh Signifikan terhadap locus of control siswa/siswi. Ini terjadi dikarenakan faktor usia dari siswa/siswi, karena pada kisaran usia tersebut pengendalian diri masih sangat rendah.

3. Berdasarkan uji hipotesis, emotional intelligence tidak berpengaruh academic achievement siswa/siswi di SMA N 9 Padang. Karna belum tentu semakin tinggi tingkat emotional intelligence, semakin baik academic achievement yang akan dicapai oleh siswa/siswi.

4. Berdasarkan uji hipotesis, locus of control tidak berpengaruh terhadap academic achievement. Sehingga penulis menyimpulkan bahwa locus of control belum dianggap sebagai faktor dalam meningkatkan academic achievement pada siswa/siswi SMA N 9 Padang. Dan juga tidak ada efek mediasi antara emotional 
intelligence dan academic achievement. Hal ini terjadi karena locus of control tidak memberikan pengaruh langsung terhadap academic achievement.

\section{REKOMENDASI}

1. Penelitian selanjutnya dapat mengumpulkan lebih dari 100 sampel untuk memperkuat validitas.

2. Penelitian perbandingan antara sekolah dapat berguna untuk menguji teori tentang tiga variabel yang dipakai pada penelitian ini.

3. Dari pembahasan hasil penelitian masih ada variabel lain yang memiliki pengaruh terhadap academic achievement, mudah-mudahan para peneliti selanjutnya akan mengidentifikasi variabel lain yang berpengaruh terhadap academic achievement.

4. Menggunakan pendekatan kualitatif juga dapat menambah data dari pendekatan-pendekatan kuantitatif. Karena responden dapat memberitahu segala sesuatu tentang pengalaman mereka dan bagaimana pengaruh emotional intelligence terhadap academic achievement. Dan yang terakhir yaitu dapat menggunakan variabel mediator selain locus of control untuk mendapatkan hasil yang berbeda dan kemungkinan lebih baik.

\section{DAFTAR PUSTAKA}

Ahmadi, A.\& Supriyono, W. (2004). Psikologi belajar. Jakarta: PT Rineka Cipta.

Anderson, A; Hattie, J. \&. Hamilton, R. (2005). Locus of control, self-efficacy and motivation in different schools: Is moderation the key to success.Educational Psychology 25 (5): 517-535.

Azwar, S. (2002). Tes prestasi: Fungsipengembangan pengukuran prestasi belajar. Yogyakarta: Pustaka Pelajar.

Azwar, S. (2004). Pengantar psikologi intelegensi. Yogyakarta: Pustaka Pelajar.

Bellamy, A., Gore, D., \& Sturgis, J. (2005). Examining the relevance of emotional intelligence within educational programs for the gifted and talented. Electronic Journal of Research in Educational Psychology, 6(3) 53-78.

Depdiknas. 2008. Kurikulum Tingkat Satuan Pendidikan. Jakarta: Dikmenum. Depdiknas.

Ikhsan, Gilang Kamil (2015). Pengaruh Emotional Intelligence Terhadap Academic Achievement: Locus of Control Sebagai Mediator. Journal Of Education

Kreitner dan Kinicki. 2005. Perilaku Organisasi, buku satu Jakarta : Salemba Empat

Marlius, D. (2018). Pengaruh Dimensi Kualitas Pelayanan Website Akademik Terhadap Kepuasan Mahasiswa Pada STIE “KBP”. Jurnal Ipteks Terapan. Volume 12. No. 2. Hal. 116-128. http://doi.org/10.22216/jit.2018.v12i2.633

Suryabrata, S. (2006). Psikologi pendidikan. Jakarta: PT RajaGrafindo Persada. Suyanto. 2009. Urgensi Pendidikan Karakter. Direkjenmanpendasmen

Sekaran, Uma. (2006). Research Methods For Business. Edisi ke-4. Salemba Empat. Jakarta. 
Rahnama, A. and Abdulmaleki, J. (2009) The Relationship of Emotional Intelligence and Creativity with Academic Achievement of Shahed University Students. Journal New Educational Thoughts, 2, 55-78.

Wilson, D.(2004). The interface of school climate and school connectedness and relationships with aggression and victimization. Journal of School Health, 74(7), 293-299. 